DOI https://doi.org/10.18551/rjoas.2017-02.19

\title{
THE INFLUENCE OF SERVICE QUALITY DIMENSIONS ON CUSTOMER SATISFACTION IN BANK JATIM, SURABAYA, INDONESIA
}

\author{
Kurniawan Gogi \\ STIE «YAPAN» Surabaya, Indonesia \\ E-mail: gogi.indo@gmail.com
}

\begin{abstract}
Service quality dimensions are able to motivate customers in Bank Jatim Surabaya to establish a strong association with the services, which in turn is expected to provide a customer satisfaction. This study aims to analyze the influence of service quality dimensions which consist of reliability, responsiveness, and empathy towards customer satisfaction in Bank Jatim, Surabaya. This study also uses a sample of 60 respondents (customers) which further tested by using a multiple linear regression analysis with F-test and t-test. Moreover, the results of this study indicate that the variable of reliability, responsiveness, and empathy have a positive and significant impact on customer satisfaction. While partially, the reliability, responsiveness, and empathy could give a positive and significant effect towards customer satisfaction. On the other hand, responsiveness is the variable which has the most dominant and significant effect on customer satisfaction. This means that these 3 dimensions of service quality have an important role in helping the needs and desires of customers to receive the best service.
\end{abstract}

\section{KEY WORDS}

Service, quality dimensions, customer, satisfaction.

In everyday life, a person cannot be separated from the fulfilment of goods and services particularly those which are related to service provision. What is meant by services here are the services in the field of banking. If you pay attention to the current banking system, its presence needs to be laid out in such particular condition along with the increasing competition of service provision in society. According to Zeithaml et al. (2002), service is an overall impression of the customer towards the inferiority or superiority of the organization and the services offered. Meanwhile, Cronin and Taylor (1992) stated that there is still no objective study concerning this matter, however, measuring the performance of the services received by the customer is usually performed in order to estimate the quality of an organization or a company.

Therefore, service quality is a form of customer ratings of the perceived service towards the expected service. Service quality is generated by the banking operation and the success of this operation is determined by many factors such as the employees, systems, technology, as well as customer engagement. Parasuraman et al. (1991) have suggested a model of service quality that highlights some of the main requirements to provide the expected service quality. Furthermore, it is emphasized that service quality is a mismatch between the expectations or desires of the customer with a customer perception. He also added that service quality has many different characteristics so that it's difficult to be defined or measured by using these service quality dimensions. This also includes a wide range of issues related to service quality, namely: tangibles, reliability, responsiveness, assurance, and empathy. However, the problems which are chosen to be examined in this study are the issue on the dimensions of reliability, responsiveness, and empathy in concern with the service quality and customer satisfaction in Bank Jatim, Surabaya.

From the description above, it is clear that service quality provides a motivation to the customers to establish a strong association with services like banking services. Nevertheless, the quality of service that is delivered to banking customers is closely linked with customer satisfaction. Anderson et al. (1997) in his research said that many researchers agree that satisfied customers tend to be more loyal to its organization. While according to 
Mudie and Cottam (1972), quoted by Tjiptono (2007), a total customer satisfaction cannot be fully achieved even only for a while. This means that the better the service quality, the higher the satisfaction felt by customers. When a higher satisfaction is received by the customer, it can create such benefits for the company. In other words, satisfied customers will continue to make purchases at the company but if the relation is performed without any satisfaction, this certainly can lead the customers to move to another product. Customer satisfaction is a function between the perceived performance and the expectation (Kotler, 2009).

Therefore, in a long-term condition, this kind of association will allow the service to carefully understand customer expectation. Thus, the existence of services which in this term is banking, requires the development and progression of better service quality so as to give a satisfaction to customers. Related to that, the framework that is outlined in this study is at least identical to the system applied in Bank Jatim, Surabaya. However, the results which were obtained are considered to be less optimal in concern with the customer expectation. Then, this thing becomes the background of Bank Jatim in their expectation and reality that is delivered as service where it is judged differently by the customers. In the context of customer satisfaction, the expectation is the estimation or beliefs of what they will receive; their expectations are formed by their first buying experience, friends' comments as well as the promise of the organization. Customer expectations will keep growing from time to time along with the increasing level of customer experience. By that, a satisfied or dissatisfied customer is the response of customer to the evolution of disconfirmation that is perceived between prior expectations and actual performance. It is felt that in this increasingly fierce competition, more banking services have involved in fulfilling the needs and desires of the customers. Of course, this makes each bank to put their orientation on customer satisfaction as a primary goal, for example, with the increasing number of services in business area which have a commitment to customer satisfaction in the mission and promotion (Tjiptono, 2007).

According to the academicians, customer satisfaction is a construct that stands alone and influenced by the quality of service (Oliver, 1980). The research on Quality, Service, Perceived Value, Customer Satisfaction, Company's Fame, and Loyalty has already been done by $\mathrm{Hu}$ and Juwaheer (2009) to the hotel guests in Mauritis in concern with the application of high-quality service and the creation of superior customer value. This can lead to high customer satisfaction so that it could affect the company's fame where it ultimately leads to customer retention. In accordance with the previous research of Wahyuningsin (2002), there is a significant influence on service quality and customer satisfaction, and in this context, the aspect of reliability from service quality dimensions has the most dominant influence on customer satisfaction. Meanwhile, Junaidi (2002) indicated that empathy is an inspiration and attention intended personally to the customer, for example, the ability to give special attention to the customer, the willingness to provide time for the customers in addressing issues, personal approach, and paying attention to the interests and needs of customers. Next, according to the customers of BNI Taplus Surakarta, empathy is the variable which considered as the most important and the most significant thing which can affect the company to improve customer satisfaction. Besides that, the variable of reliability, responsiveness, and assurance are the variable that can be considered to have an important and significant influence to improve satisfaction. As for the tangibles variable, unfortunately, this has not been assessed as an important and significant influence to improve satisfaction. Therefore, this study aims to: 1) analyze the influence of service quality dimensions which consist of reliability, responsiveness, and empathy simultaneously to customer satisfaction in Bank Jatim, Surabaya, 2) examine the effect of service quality dimensions including reliability, responsiveness, and empathy partially to customer satisfaction in Bank Jatim, Surabaya, as well as to analyze one factor among the service quality dimensions such as reliability, responsiveness, and empathy that has a dominant influence on customer satisfaction in Bank Jatim, Surabaya. 


\section{METHODS OF RESEARCH}

This research was carried out by using a correlation study in order to examine the effect or correlation between several research variables (Munir, 2013). The design was used either to test or to confirm the relationship or influence between the variables. The study was conducted in Bank Jatim, Surabaya from November to December 2013. Moreover, the sampling technique was performed by census method due to limited research time, and there were 60 respondents (customer) chosen. Furthermore, the analysis was done by using multiple linear regression analysis with the F-test and t-test.

\section{RESULTS AND DISCUSSION}

The simultaneous test results can be seen in this following table:

Table 1 - F-test Analysis

\begin{tabular}{|c|c|c|c|c|c|c|}
\hline \multicolumn{2}{|c|}{ Model } & Sum of Squares & Df & Mean Square & F & Sig. \\
\hline \multirow{3}{*}{1} & Regression & 152.936 & 3 & 50.979 & 80.085 & $.000^{\mathrm{a}}$ \\
\cline { 2 - 7 } & Residual & 35.647 & 56 & .637 & & \\
\cline { 2 - 7 } & Total & 188.583 & 59 & & & \\
\hline
\end{tabular}

Source: Results of regression analysis.

Based on Table 1 above, the result of F-test analysis shows a number of 80,085 with a significance level of $0,000<0,05$. The results of the overall analysis of the three independent variables (reliability, responsiveness, and empathy) have a positive and significant impact on customer satisfaction in Bank Jatim, Surabaya. This means that $\mathrm{Ho}$ is rejected and $\mathrm{Ha}$ is accepted. On the other hand, the partial test results are illustrated as follows:

Table 2 - T-test Analysis

\begin{tabular}{|c|c|c|c|c|c|}
\hline & \multirow{2}{*}{ Model } & \multicolumn{2}{|c|}{ Unstandardized Coefficients } & \multirow{2}{*}{$\mathrm{T}$} & \multirow{2}{*}{ Sig. } \\
\hline & & B & Std. Error & & \\
\hline \multirow{4}{*}{1} & (Constant) & -.843 & .913 & -.924 & .359 \\
\hline & Reliability (X1) & .312 & .056 & 5.587 & .000 \\
\hline & Responsiveness (X2) & .358 & .045 & 8.037 & .000 \\
\hline & Emphaty (X3) & .619 & .119 & 5.207 & .000 \\
\hline
\end{tabular}

Source: Results of regression analysis.

As we can see, Table 2 indicates that: Reliability has a positive and significant impact on customer satisfaction in Bank Jatim, Surabaya with the coefficient of 0,312 and t-test analysis result by 5,587 at a significance level of $0,000<0,05$. This means that Ho is rejected and $\mathrm{Ha}$ is accepted.

Responsiveness is able to give a positive and significant effect on customer satisfaction in Bank Jatim, Surabaya with the coefficient number of 0,358 and t-test analysis result by 8,037 at a significance level of $0,000<0,05$ ( $\mathrm{Ho}$ is rejected and $\mathrm{Ha}$ is accepted).

Empathy could influence customer satisfaction positively and significantly in Bank Jatim, Surabaya with the coefficient of 0,619 and t-test analysis result by 5,207 at a significance level of $0,000<0,05$. This shows that $\mathrm{Ho}$ is rejected and $\mathrm{Ha}$ is accepted.

Then, the test of dominant influence on one variable has resulted in this table below:

Table 3 - Dominant Test Analysis

\begin{tabular}{|c|c|c|}
\hline & \multirow{2}{*}{ Model } & \multirow{2}{*}{$\begin{array}{c}\text { Standardized Coefficients } \\
\text { Beta }\end{array}$} \\
\hline & & \\
\hline \multirow{4}{*}{1} & (Constant) & \\
\hline & Reliability (X1) & .387 \\
\hline & Responsiveness (X2) & .481 \\
\hline & Emphaty (X3) & .362 \\
\hline
\end{tabular}

Source: Results of regression analysis 
Table 3 shows that responsiveness has a dominant and significant influence (most influential) towards customer satisfaction in Bank Jatim, Surabaya, with the results of standardized coefficients (beta) by 0,481 in which it means that $\mathrm{Ho}$ is rejected and $\mathrm{Ha}$ is accepted.

Furthermore, the results of this study stated that the 3 variables such as reliability, responsiveness, and empathy are considered as an important variable which has a significant influence on customer satisfaction in Bank Jatim, Surabaya. Thus, the results of this customer satisfaction test are able to be a monitoring indicator for the service quality in Bank Jatim Surabaya so that the expectations of the customers will be well received. The results of this study are similar to the study of Wahyuningsih (2002), Junaidi (2002), as well as Cahyadi (2003). Similarly, the results of the analysis also indicated that each service quality dimension has an important role that could affect customer satisfaction in Bank Jatim, Surabaya. By that, the result of this dominance and significance test could show a high achievement and as an improvement in giving their best to the customers so that customer expectations can be obtained in accordance with the real perception in demonstrating its service quality. The results of this test are consistent with the results of Lai \& Babin (2009) and Hu \& Juwaheer (2009).

\section{CONCLUSION}

From the result and discussion above, we can pull out a conclusion such as: The results of the overall analysis of the 3 independent variables (reliability, responsiveness, and empathy) have a positive and significant impact on customer satisfaction in Bank Jatim, Surabaya. This means that the higher the service quality provided, the higher the satisfaction received by customers.

The results of the analysis of each dimension such as reliability, responsiveness, and empathy show a positive and significant impact on customer satisfaction in Bank Jatim, Surabaya. This result is related to the service quality improvement of the human resources or employees at Bank Jatim, Surabaya in assisting and responding the needs and desires of customers with a fast and reliable response.

Responsiveness has a dominant and significant effect on customer satisfaction in Bank Jatim, Surabaya because it is proven as an important thing which has the highest impact on the service provision.

\section{SUGGESTIONS}

After what we have discussed previously, the suggestions for Bank Jatim, Surabaya are as follows:

The party of Bank Jatim, Surabaya is expected to pay more attention and to retain the service quality dimensions especially in terms of the employees. This means that employees must provide accurate information and be responsive in dealing with complaints from customers as well as provide hospitality which complies the requirements of the customers.

It is also assumed that Bank Jatim need to improve the service quality so that it would be a better service. With excellent service quality, the customer will be satisfied so that it could enhance the positive image in the eyes of the customers in which it will ultimately create a customer's loyalty.

The success of Bank Jatim in responding customers indicates that Bank Jatim has already understood the customer so that it needs an improvement to increase the quality. This is due to responsiveness variable that has a strong influence on customer satisfaction in which it is expected to be the attention in the future.

\section{REFERENCES}

1. Anderson, E.W. et al (1997). Customer satisfaction, productivity, and profitability: difference between goods and services. Marketing Science, 16(2):129-145. 
2. Cahyadi, E. (2003). Kualitas Pelayanan, Kepuasan dan Loyalitas Pelanggan Pada Industri perbankan Islam Dengan Menggunakan Metode CARTER (Kasus Bank Mualamat Indonesia Cabang Rawamangun). Skripsi. Unpublished. Fakultas IImu Sosial dan IImu Politik Universitas Indonesia, Jakarta.

3. Cronin, J.J Jr. and Taylor, S.A. (1992). Measuring Service Quality, A Reexamination and Extension. Journal of Marketing, 56 (55-68).

4. Hu, J.K. \& Juwaheer, T. (2009). Relationships and impacts of service quality, perceived value, customer satisfaction, and image. Jurnal Administrasi Bisnis (JAB), Vol. 6 No. 2.

5. Junaidi, S. (2002). Pengaruh Ketidakpuasan Konsumen, Karakteristik Kategori Produk, dan Kebutuhan Mencari Variasi Terhadap Keputusan Perpindahan Merek. Jurnal Ekonomi dan Bisnis Indonesia.

6. Kandampully, J. And Juwaheer, T. (2009). Relationships and impacts of service quality, perceived value, customer satisfaction, and image: an empirical study. The Services Industries Journal, 29 (2): 111-125.

7. Kotler, P. (2009). Marketing Management. $11^{\text {th }}$ Edition. Prentice Hall.Inc., New Jersey.

8. Lai, M.G. \& Babin, B.J. (2009). How quality, value image, and satisfaction create loyalty at a Chinese telecom. Journal of Business Research, 62 (2009) 980-986.

9. Mudie, P. and Cottam, A. 1993. The Management and Marketing of Services. Butterworth - Heinemann Ltd, Oxford.

10. Munir, R.M. (2013). Metode Penelitian: Suatu Pendekatan Untuk Penelitian Tindakan. Edisi Pertama. $1^{\text {st }}$ Edition. UPNV Jawa Timur, Surabaya.

11. Oliver, R.L. (1980). A cognitive model of the antecedents and consequences of satisfaction decision. Journal of Marketing Research, 17 (4): 460-469.

12. Parasuraman, A., Zeithml, V.A., \& Berry, L.L. (1991). SERVQUAL: A Multiple Item Scale for Meansuring Consumer Perseption of Service Quality. Jurnal of Retailing.

13. Tjiptono, F. (2007). Manajemen Jasa. Penerbit Andi Offset, Yogyakarta.

14. Zeithaml, V.A. and Bitner, M.J. (2002). Service Marketing. Int'l Edition. McGraw Hill Inc., New York.

15. Wahyuningsih, A. (2002). Analisa Tingkat Kepuasan Konsumen Berdasarkan Kualitas Pelayanan pada Rumah Sakit Umum Kabupaten Karang Anyer, Jakarta. Unpublished Undergraduate Thesis, Fakultas Ekonomi Program Studi Manajemen, UMS. 